\title{
Tetramethylpyrazine protects Schwann cells from ischemia-like injury and increases cell survival in cold ischemic rat nerves
}

\author{
Ming-Ming Yang, Wei Huang, Dian-Ming Jiang* \\ Department of Orthopedics, The First Affiliated Hospital of Chongqing Medical University, Chongqing, \\ People's Republic of China
}

\begin{abstract}
Tetramethylpyrazine (TMP), a major active ingredient of Ligusticum wallichi Franchat extract (a Chinese herb), exhibits neuroprotective properties in ischemia. In this study, we assessed its protective effects on Schwann cells (SCs) by culturing them in the presence of oxygen glucose deprivation (OGD) conditions and measuring cell survival in cold ischemic rat nerves. In the OGD-induced ischemic injury model of SCs, we demonstrated that TMP treatment not only reduced OGD-induced cell viability losses, cell death, and apoptosis of SCs in a dose-dependent manner, and inhibited LDH release, but also suppressed OGD-induced downregulation of Bcl-2 and upregulation of Bax and caspase-3, as well as inhibited the consequent activation of caspase-3. In the cold ischemic nerve model, we found that prolonged cold ischemic exposure for four weeks was markedly associated with the absence of SCs, a decrease in cell viability, and apoptosis in preserved nerve segments incubated in University of Wisconsin solution (UWS) alone. However, TMP attenuated nerve segment damage by preserving SCs and antagonizing the decrease in nerve fiber viability and increase in TUNEL-positive cells in a dose-dependent manner. Collectively, our results indicate that TMP not only provides protective effects in an ischemia-like injury model of cultured rat SCs by regulating Bcl-2, Bax, and caspase-3, but also increases cell survival and suppresses apoptosis in the cold ischemic nerve model after prolonged ischemic exposure for four weeks. Therefore, TMP may be a novel and effective therapeutic strategy for preventing peripheral nervous system ischemic diseases and improving peripheral nerve storage.
\end{abstract}

Uniterms: Tetramethylpyrazine. Schwann cell. Oxygen glucose/deprivation. Peripheral nerve. Ischemia/ experimental study. University of Wisconsin solution.

Tetrametilpirazina (TMP), o principal componente do extrato de Ligusticum wallichi Franchat (erva chinesa), apresenta propriedades neuroprotetoras na isquemia. Nesse estudo, avaliamos seus efeitos protetores nas células de Schwann (SC), cultivando-as na presença de condições de depleção de oxigênio da glicose (OGD) e medindo a sobrevivência dos nervos de ratos isquêmicos pelo resfriamento. No modelo de lesão isquêmica em SC induzida por OGD, demonstramos que o tratamento com TMP não somente reduziu as perdas de viabilidade celular induzida por OGD, a morte celular, a apoptose de SC dose-dependente e inibiu a liberação de $\mathrm{LDH}$, mas, também, suprimiu a infra-regulação do Vcl-2 e a supra-regulação de Bax e caspase-3, e inibiu a consequente ativação da caspase-3. No modelo de nervo isquêmico por resfriamento, observamos que a exposição prolongada ao resfriamento por quatro semanas estava, marcadamente, associada com a ausência de SC, com o decréscimo da viabilidade celular e a apoptose em segmentos de nervo incubados na solução da Universidade de Wisconsin apenas. Entretanto, a TMP atenuou o dano no segmento do nervo preservando SC e antagonizando a diminuição da viabilidade da fibra nervosa e o aumento das células TUNEL-positiva de modo dose-dependente. De forma conjunta, nossos resultados indicam que o TMP não só fornece efeitos protetores em um modelo de dano semelhante à isquemia de $\mathrm{SC}$ de ratos cultivados pela regulação de $\mathrm{BCl}-2$, Bax e caspase 3 , mas, também, aumenta a sobrevivência celular e suprime a apoptose no modelo de isquemia por resfriamento por exposição prolongada por quatro semanas. Então, TMP pode ser uma estratégia terapêutica eficaz para prevenir doenças isquêmicas do sistema nervoso periférico e melhora a armazenagem do nervo periférico.

Unitermos: Tetrametilpirazina. Célula de Schwann. Oxigênio da glicose/depleção. Nervo periférico. Isquemia/tratamento/estudo experimental. Solução da Universidade de Wisconsin.

"Correspondence: Dian-Ming Jiang. Department of Orthopedics, The First Affiliated Hospital of Chongqing Medical University, Chongqing 400016, People's Republic of China. E-mail: jiangdm1957@163.com 


\section{INTRODUCTION}

Nerve autografts have remained the gold standard for peripheral nerve gap repair for over 50 years. However, peripheral nerve injuries with extensive nerve deficits are still a challenge to reconstructive surgeons, which is compounded by limited amount of expendable nerves available for autografts and the inevitable and concomitant donor site morbidity that is associated with harvesting autografts. Tubulization techniques, including biological conduits (artery (Itoh et al., 1996) or vein (Chiu et al., 1982)) and artificial conduits (silicone or polyglycolic acid polymer), are only feasible for repairing short nerve gaps (Mackinnon, 1989; Siemionow, Brzezicki, 2009). Advancements in our understanding of alloimmunity have resulted in a renewed interest in nerve allografts, which are now considered to be an available option for massive nerve tissue loss and a useful alternative to nerve autografts. The first description of the use of human peripheral nerve allografts provided encouraging results (Mackinnon, Hudson, 1992). However, peripheral nerve allograft transplantation requires tissue typing of both the donor and the recipient, and often transportation of graft materials over long distances. These preoperative requirements can result in variable storage times and conditions between the time of harvesting of the graft from the organ donor and implantation into the host. If an optimal storage method can be developed whereby peripheral nerves can be preserved for a sufficient amount of time for transport, then nerve allografts would be the first choice in peripheral nerve injury reconstruction. Ideally, the preservation of peripheral nerve grafts would result in the establishment of a nerve tissue bank.

The maintenance of Schwann cell (SC) viability in peripheral nerves during cold storage appears to be an important determinant in the successful repair of massive nerve deficits. SCs are the major cellular component of peripheral nerves and are vital in the axonal regeneration process. It has been reported that acellular nerve grafts generally fail to support axonal regeneration beyond $3 \mathrm{~cm}$ (Hess et al., 2007). Ideally, the ability to successfully preserve nerve grafts prior to transplantation would ensure that the time needed to meet preoperative requirements would not jeopardize the viability of the grafts.

University of Wisconsin solution (UWS) is commonly used for flushing and cold storage of solid organs. This well-established cold storage medium has also been used for preserving segments of peripheral nerves, but it was shown that peripheral nerve segments stored in UWS over a long period of time ( $\geq 3$ weeks) resulted in nerves with few viable SCs that were essentially acellular conduits (Levi et al., 1994). Ischemic injury may be partly responsible for the decrease in viable SCs, because it can initiate a cascade of events that results in cell death by apoptosis and necrosis (Faubel, Edelstein, 2005).

Tetramethylpyrazine (TMP), one of the major and most important active ingredients of traditional Chinese medicine Ligusticum wallichii Franchat (Chuan Xiong), has been used to treat ischemic disorders for many years (Chun-Sheng et al., 1978; Ho, Wen, Lee, 1989). However, limited data exist on the protective effect of TMP on ischemia-like injury of SCs, and no reports have described the use of a TMP solution for nerve tissue preservation. In this study, we examined the protective effects of TMP in an oxygen glucose deprivation (OGD)-induced SCs injury model, and explored the possible mechanism for the observations (Study 1). In addition, we hypothesized that TMP may increase cell survival in a cold ischemic rat nerve model after prolonged ischemia exposure of up to four weeks (Study 2), which would improve peripheral nerve storage, allow longer periods of preservation, and aid in peripheral nerve allotransplantation clinically available.

\section{MATERIAL AND METHODS}

All animal care procedures complied with the guidelines of the Chongqing Medical University Animal Care and Use Committee and the study was approved by the ethics committee of Chongqing Medical University.

\section{Chemicals and reagents}

TMP (purity >98\%), dimethylsulfoxide (DMSO), collagenase, trypsin, basic fibroblast growth factor (bFGF), cytosine arabinoside, and 3-[4, 5-dimethylthiazol2-yl]-2,5-diphenyl-ltetrazolium bromide (MTT) were obtained from Sigma (St. Louis, MO, USA). The LIVE/ DEAD Viability/Cytotoxicity Kit was purchased from Molecular Probes (Eugene, OR, USA). The lactate dehydrogenase (LDH) assay kit was purchased from the Nanjing Jiancheng Bioengineering Institute (Nanjing, China). The Annexin V-FITC and propidium iodide (PI) apoptosis detection kits were obtained from KeyGen Biotech (JiangSu, China). Antibodies against S-100, Bax, Bcl-2, and $\beta$-actin, as well as a horseradish peroxidase (HRP) conjugated secondary antibody were purchased from Santa Cruz Biotechnology (Santa Cruz, CA, USA). The antibody against caspase-3 was obtained from Cell Signaling Technology (Beverly, Ma, USA). Dulbecco's modified Eagle's medium (DMEM) and fetal bovine 
serum (FBS) were purchased from Gibco (Grand Island, NY, USA). University of Wisconsin solution (UWS) was obtained from Bristol-Myers Squibb Company (Princeton, New Jersey, USA).

\section{Study 1}

\section{Schwann cell cultures}

SC cultures were obtained using the method described in Brockes et al., 1980, with minor modifications. Briefly, sciatic nerves from 2-3-day-old Sprague-Dawley rats were harvested and digested with $0.1 \%$ collagenase and $0.25 \%$ trypsin at $37{ }^{\circ} \mathrm{C}$ for $15 \mathrm{~min}$. Twenty-four hours after planting, the cells were treated with cytosine arabinoside for $48 \mathrm{~h}$ to eliminate proliferating fibroblasts. Following this treatment, the culture medium was replaced with fresh medium supplemented with $20 \mathrm{ng} / \mathrm{mL}$ bFGF to allow for SC proliferation. After eight days, the SCs were detached with $0.1 \%$ EDTA-trypsin and passaged. The culture medium was changed three times per week. Cultured cells were fixed with $4 \%$ paraformaldehyde and the purity of SCs was assessed by immunochemical staining of S-100 protein.

\section{Oxygen glucose deprivation (OGD)}

OGD was induced according to the method described by Keihoff et al., 2008. To initiate OGD, the original cell culture medium was removed and cells were gently washed with a glucose-free phosphate-buffered saline (PBS). Cells were then incubated in a fresh glucosefree salt buffer solution containing $109.5 \mathrm{mM} \mathrm{NaCl}, 5.4$ $\mathrm{mM} \mathrm{KCl}, 1.8 \mathrm{mM} \mathrm{CaCl}_{2}, 0.8 \mathrm{mM} \mathrm{MgSO}_{4}, 25 \mathrm{mM}$ HEPES 25 , and $0.91 \mathrm{mM} \mathrm{NaH}_{2} \mathrm{PO}_{4}$. The cells were maintained in a hypoxic environment in a tri-gas cell culture incubator (Thermo Fisher Scientific, Basingstoke, UK) flushed with $5 \% \mathrm{CO}_{2}$ and $95 \% \mathrm{~N}_{2}$ for $6 \mathrm{~h}$ followed by $1 \mathrm{~h}$ of reoxygenation in a standard incubator with $5 \% \mathrm{CO}_{2}$. The concentration of oxygen, which was lower than $1 \%$, was determined by an oxygen analyzer (Vascular Technology, $\mathrm{NH}$, USA). TMP was freshly prepared as a stock solution with dimethylsulfoxide (DMSO) and diluted with PBS ( $\mathrm{pH}$ 7.3). The final concentration of DMSO added to the cells never exceeded $0.1 \%$. A $0.1 \%$ solution of DMSO, which was the highest concentration in the medium, was used as a vehicle control. TMP $(0,25,50,100$ or $200 \mu \mathrm{g} /$ $\mathrm{mL}$ ) was added to the culture at the start of OGD exposure and continued until the SC cultures were collected and analyzed. Normal control cultures were always maintained in normal medium under normal incubation conditions. The second passage of SCs were exposed to OGD and treated with TMP, and cells at $80 \%$ confluence were used for all experiments. Three replicates were used for each experiment.

\section{Cell viability analysis}

Cell viability was evaluated by two methods: an MTT assay and calcein-AM/ethidium homodimer I (EthD-I) staining. For the MTT assay, the MTT solution $(20 \mu \mathrm{l})$ in PBS was added to each well at a final concentration of $5 \mathrm{mg} / \mathrm{mL}$ and then incubated for an additional $4 \mathrm{~h}$ at $37^{\circ} \mathrm{C}$. The medium containing MTT was then removed and the blue MTT-formazan complex was dissolved in DMSO $(100 \mu \mathrm{L})$. Optical density (OD) values were measured on a microplate reader at a wavelength of $570 \mathrm{~nm}$. Cell viability rates were expressed as the mean percentage of values of normal control cells.

A LIVE/DEAD Viability/Cytotoxicity Kit was also used to measure cell viability, which takes advantage of the phenomenon that living cells are able to hydrolyze calceinAM $(2 \mu \mathrm{M})$ by intracellular esterases resulting in green fluorescence. In parallel, dead cells were labeled with ethidium homodimer I (EthD-I, $4 \mu \mathrm{M}$ ), which interacts with nucleic acids to yield a red fluorescence in cell nuclei. Each reagent was incubated with the cells for $30 \mathrm{~min}$ and then assessed on a fluorescence microscope.

\section{LDH release assay}

Cell cytotoxicity was quantitatively assessed by measuring the amount of LDH released from the damaged cells into the culture medium. LDH release into the culture medium was detected using a cytotoxicity detection kit according to the manufacturer's instructions. Cultures under normal conditions (normal control group) represented basal LDH release, and the data were expressed as the mean percent of the maximal LDH released in the OGD alone group.

\section{Analysis of apoptosis by flow cytometry}

Apoptosis was measured by annexin V-FITC/PI staining and flow cytometry. Briefly, cells were harvested after the treatment and resuspended in PBS at a density of $10^{6}$ cells $/ \mathrm{mL}$ ). Aliquots of $10^{5}$ cells were stained with $5 \mu \mathrm{L}$ of annexin V-FITC and $10 \mu \mathrm{L}$ of PI for $15 \mathrm{~min}$ at room temperature in the dark. The apoptosis rates were then quantified with a FACS Vantage SE flow cytometer (BD Biosciences, San Jose, Calif., USA). The cell populations of annexin $\mathrm{V}^{+} / \mathrm{PI}^{-}$and annexin $\mathrm{V}^{+} / \mathrm{PI}^{+}$were calculated as a representation of apoptotic cells.

\section{Real-Time PCR analysis}

Total RNA was isolated from SCs by extraction with Trizol (Invitrogen) according to the manufacturer's 
instructions, and the RNA concentration was measured by ultraviolet spectroscopy. Primers were designed and synthesized by Shanghai Sangon (Shanghai, China), with $\beta$-actin used as an endogenous control for gene expression analysis. The primer sequences were as follows: Bax forward, 5'-ATG GCT GGG GAG ACA CCT GA-3'; Bax reverse, 5'-GCA AAG TAG AAG AGG GCA ACC-3'; Bcl-2 forward, 5'-CCT TCT TTG AGT TCG GTG-3'; Bcl-2 reverse, 5'-GAG ACA GCC AGG AGA AAT-3'; Caspase-3 forward, 5'-ATG CTT ACT CTA CCG CAC CCG-3'; Caspase-3 reverse, 5'-GGT TAA CAC GAG TGA GGA TGT GC-3'; $\beta$-actin forward, 5'-CGT TGA CAT CCG TAA AGA CCT C-3'; and $\beta$-actin reverse, 5'TAG GAG CCA GGG CAG TAA TCT-3'. Quantitative real-time PCR was performed using the $\mathrm{SYBR}^{\mathrm{TM}}$ Green real-time PCR Master Mix kit (TaKaRa, Japan) according to the manufacturer's instructions, on a SLAN ${ }^{\circledR}$ Real-Time PCR Detection System (Hongshi Medical Technology Co., Ltd, Shanghai, China). The PCR cycling conditions were as follows: $95^{\circ} \mathrm{C}$ for $1 \mathrm{~min}$, followed by 40 cycles of denaturation at $95^{\circ} \mathrm{C}$ for $15 \mathrm{~s}$, annealing at $58^{\circ} \mathrm{C}$ for $20 \mathrm{~s}$, and extension at $72^{\circ} \mathrm{C}$ for $20 \mathrm{~s}$. The relative transcript amount of target gene was normalized to that of $\beta$-actin using the $2^{-\Delta \Delta \mathrm{ct}}$ method, as previously described (Livak, Schmittgen, 2001).

\section{Western blot analysis}

SCs $\left(1.0 \times 10^{6}\right)$ from the different treatment groups were lysed in $200 \mu \mathrm{L}$ lysis buffer (Beyotime Institute of Biotechnology, JiangSu, China) containing $100 \mathrm{mM}$ phenylmethylsulfonyl fluoride (PMSF; Sigma) on ice for $30 \mathrm{~min}$ and then centrifuged at 14,000 $\mathrm{x}$ g for $10 \mathrm{~min}$ at $4{ }^{\circ} \mathrm{C}$. Protein quantification was performed with the Bradford reagent (Beyotime Institute of Biotechnology, JiangSu, China). Protein samples were boiled for $10 \mathrm{~min}$ with loading buffer and then separated on $12 \%$ SDSPAGE gels. Each lane was loaded with $40 \mu \mathrm{g}$ protein. After separation, the proteins were transferred to polyvinylidene fluoride (PVDF) membranes (Millipore, USA), and the membranes were blocked in $0.05 \%$ Tween-20 in TBS (TBS-T) containing 5\% nonfat milk for $1 \mathrm{~h}$. The membranes were then incubated overnight with antibodies to Bax (1:200 dilution), Bcl-2 (1:200 dilution), and caspase-3 (1:1000 dilution), followed by incubation with the respective HRP-conjugated secondary antibodies (1:2000 dilution). In addition, $\beta$-actin (1:1000 dilution) was used as a loading control to normalize the samples. Immunoblots were developed by enhanced chemiluminescence (ECL) (Pierce, USA). Quantitative analysis of the visualized protein bands was performed using an AlphaEaseFC imaging system (Alpha Innotech).

\section{Study 2}

\section{Harvesting and preserving nerve grafts}

Forty-two adult male Sprague-Dawley rats weighing 200-250g were deeply anesthetized by an intraperitoneal injection of chloral hydrate $(300 \mathrm{mg} / \mathrm{kg})$. Both sciatic nerves were removed under sterile technique using a muscle splitting incision. The nerve was transected proximally at the sciatic notch and distally at the point of trifurcation to harvest a $15 \mathrm{~mm}$ nerve graft segment. After the bilateral sciatic nerves were excised, the animals were sacrificed by cervical dislocation while still anesthetized. The nerve segments $(n=84)$ were divided randomly into six equal groups:

- $\quad$ Fresh-nerve group $(\mathrm{n}=14)$ : Nerve segments were removed without any storage.

- $\quad 100 \mathrm{mg} / \mathrm{mL}$ TMP-nerve group ( $\mathrm{n}=14)$ : Nerve segments were immersed in UWS containing TMP $(100 \mathrm{mg} / \mathrm{mL})$ for 4 weeks at $4{ }^{\circ} \mathrm{C}$.

- $\quad 200 \mathrm{mg} / \mathrm{mL}$ TMP-nerve group ( $\mathrm{n}=14)$ : Nerve segments were immersed in UWS containing TMP $(200 \mathrm{mg} / \mathrm{mL})$ for 4 weeks at $4{ }^{\circ} \mathrm{C}$.

- $\quad 300 \mathrm{mg} / \mathrm{mL}$ TMP-nerve group ( $\mathrm{n}=14)$ : Nerve segments were immersed in UWS containing TMP $(300 \mathrm{mg} / \mathrm{mL})$ for 4 weeks at $4{ }^{\circ} \mathrm{C}$.

- $\quad 400 \mathrm{mg} / \mathrm{mL}$ TMP-nerve group $(\mathrm{n}=14)$ : Nerve segments were immersed in UWS containing TMP $(400 \mathrm{mg} / \mathrm{mL})$ for 4 weeks at $4{ }^{\circ} \mathrm{C}$.

- $\quad U W-n e r v e ~ g r o u p ~(n=14):$ Nerve segments were immersed in UWS containing $0.1 \%$ DMSO for 4 weeks at $4{ }^{\circ} \mathrm{C}$.

TMP was freshly prepared as a stock solution with DMSO. Importantly, the final concentration of DMSO added to UWS never exceeded $0.1 \%$. UWS was prepared immediately before nerve harvesting with the following additives: $200000 \mathrm{U} / \mathrm{L}$ penicillin $\mathrm{G}, 40 \mathrm{U} / \mathrm{L}$ humulin, and $16 \mathrm{mg} / \mathrm{L}$ dexamethasone.

\section{Electron microscopy}

Three nerve segments from each study group were fixed in $3 \%(\mathrm{v} / \mathrm{v})$ phosphate-buffered glutaraldehyde solution, post-fixed with $1 \%(\mathrm{w} / \mathrm{v})$ phosphate-buffered osmic acid, and finally embedded in epoxy resin. Ultrathin sections of the nerve segments were stained with $5 \%(\mathrm{w} / \mathrm{v})$ uranyl acetate in $70 \%$ methanol and lead citrate, dried, and then examined using transmission electron microscopy (TEM; Hitachi H-7500, Japan).

\section{Assessment of nerve viability}

Nerve viability was assessed by the method described by Matsumoto et al. (2005). Six nerve segments 
of each study group were directly stained with a calceinAM/EthD-I stain (Live/Dead Viability/Cytotoxity Kit) to investigate the viability of the cells of the nerve segments as described above for the SCs.

\section{TUNEL staining}

For the TUNEL assay, five nerve segments from each study group were fixed in freshly prepared $4 \%$ paraformaldehyde-PBS solution, embedded in paraffin, and then cut in $5 \mu \mathrm{m}$ thick sections. The nerve tissue section was stained using an in situ apoptosis detection kit according to the manufacturer's instructions (Roche, SUI). The total number of TUNEL-positive cells was counted in five random microscopic fields (original magnification 400x) from each section. Data were expressed as the number of TUNEL-positive cells per field.

\section{Statistical analysis}

Experimental data were analyzed using the statistical software package SPSS 16.0 (IBM, USA). All data were presented as mean \pm standard deviations (SD). Statistical differences among multiple groups were evaluated by one-way analysis of variance (ANOVA) followed by the least significant difference multiple-comparisons test as appropriate. A $P$-value $<0.05$ was considered statistically significant.

\section{RESULTS}

\section{Study 1}

\section{Primary cultured SCS with high purity}

To assess the purity of the culture, we used a rabbit polyclonal antibody raised against S-100 to immunostain primary cultured SCs. S-100, which is a specific SC marker, is a calcium-binding protein. Cultures were stained with an anti-S-100 antibody to mark the SCs (green), and all cells showed Hoechst 33342 nuclear labeling (blue). The merged images from confocal fluorescence imaging, and the blue nuclei that overlapped with the green cell bodies were identified as SCs, while other cells present in the cultures were fibroblasts. Approximately $90 \%$ of the cells in the primary culture were verified as SCs (Figure 1).

\section{Protective effects of TMP on SCs against OGD induced injury}

We found that OGD induced substantial cell injury, as indicated by the MTT assay and calcein-AM/ EthD-I staining. As shown in Figure 2, SC viability was markedly decreased after the cells were exposed to OGD.

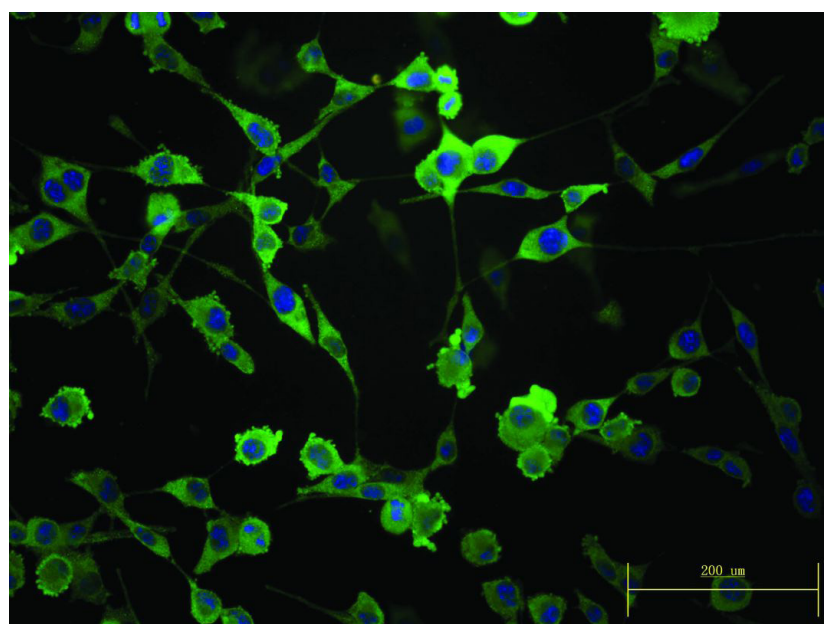

FIGURE 1 - Immunohistochemistry of primary cultured SCs. The S-100 positive cells (green) represent SCs, and all cells showed Hoechst 33342 nuclear labeling (blue). Scale bar: $200 \mu \mathrm{m}$.

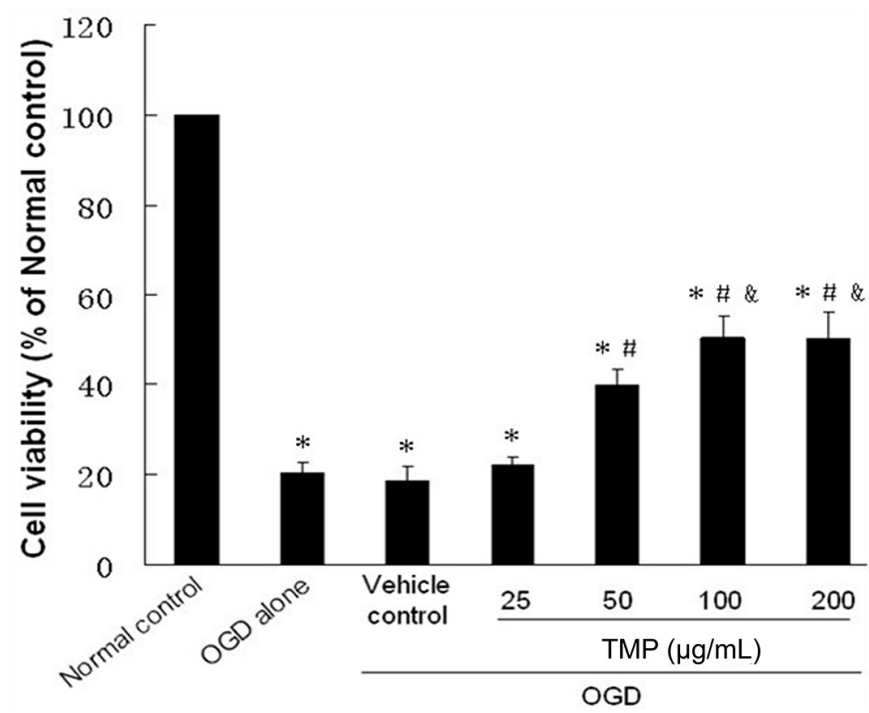

FIGURE 2 - MTT assay. The effects of TMP on SC viability subjected to OGD were assessed with the MTT reduction test. Data are expressed as the mean percentage of values of the normal control group. Values are expressed as mean \pm standard deviation (SD). ${ }^{*} P<0.05$ vs. normal control group. ${ }^{\sharp} P<0.05$ vs. cells exposed to OGD alone. ${ }^{\&} P<0.05$ vs. $50 \mu \mathrm{g} / \mathrm{mL}$ TMP group.

The viability of the OGD alone group and vehicle control group (20.22 \pm 2.34 and $18.62 \pm 3.22 \%$, respectively) was significantly lower than the normal control group (both $P<0.01)$. In addition, the difference between the OGD alone group and vehicle control group was not statistically significant $(P>0.05)$, which indicated that the vehicle $(0.1 \% \mathrm{DMSO})$ had no additional deleterious effect on the viability of SCs. When the cells were treated with 50, 100, or $200 \mu \mathrm{g} / \mathrm{mL}$ TMP, the OGD-induced cell toxicity was 
significantly attenuated in a TMP dose-dependent manner, and cell viabilities increased to $39.70 \pm 3.70,50.41 \pm 4.80$, and $50.09 \pm 5.97 \%$, respectively, compared to the OGD alone group (all $P<0.05$ ). However, treatment with $25 \mu \mathrm{g} / \mathrm{mL}$ TMP provided no significant protection of OGD-induced cell toxicity compared to the OGD alone group $(22.14 \pm 1.68$ vs. $20.22 \pm 2.34 \%$, respectively, $P>0.05)$. Inhibition of SC death with TMP was also confirmed by double-labeling with calcein-AM/EthD-I (Figure 3).

ALDH colorimetric assay was used to quantify cell death. As shown in Figure 4, LDH leakage significantly increased after OGD exposure compared to the normal control group $(14.26 \pm 0.48 \%, P<0.05)$. Importantly, TMP $(50,100$, and $200 \mu \mathrm{g} / \mathrm{mL})$ significantly attenuated OGDinduced cell death, which reduced the LDH release to $51.50 \pm 5.17,44.43 \pm 5.72$, and $46.42 \pm 3.50 \%$, respectively, compared to the OGD alone group (all $P<0.05$ ). However, treatment with $25 \mu \mathrm{g} / \mathrm{ml}$ TMP $(95.52 \pm 3.34 \%)$ provided no significant protection of OGD-induced cell death compared to the OGD alone group $(P>0.05)$. In addition, no statistically significant difference was found between the OGD alone and vehicle control groups $(98.70 \pm 6.33 \%$, $P>0.05)$.

\section{Protective effects of TMP on SCs against OGD- induced apoptosis}

In order to verify whether TMP could protect cells from OGD-induced apoptotic death, further analyses using annexin V-FITC/PI staining were performed. The cell populations of annexin $\mathrm{V}^{+} / \mathrm{PI}^{-}$and annexin $\mathrm{V}^{+} / \mathrm{PI}^{+}$were calculated as a representation of apoptotic cells, respectively, and the data were presented as the percentage of apoptotic cells. As shown in Figure 5, treatment of SCs with OGD significantly induced cell apoptosis compared to the normal control $(23.83 \pm 6.59$ vs. $4.44 \pm 0.86 \%$, respectively, $P<0.05$ ), and no statistically significant difference was found between the OGD alone and vehicle control groups $(23.83 \pm 6.59$ vs. $22.83 \pm 7.03 \%$, respectively, $P>0.05$ ). Treatment with $25,50,100$, and $200 \mu \mathrm{g} / \mathrm{mLTMP}$ significantly attenuated OGD-induced apoptosis compared to the OGD alone group $(17.60 \pm 5.73$, $11.43 \pm 2.48,6.78 \pm 1.10$, and $7.18 \pm 0.86$ vs. $23.83 \pm 6.59 \%$, respectively, all $P<0.05$ ).

Since the highest cell viability and lowest level of LDH release and percentage of apoptotic cells was detected in the 100 or $200 \mu \mathrm{g} / \mathrm{mL}$ TMP treatment groups, the $100 \mu \mathrm{g} / \mathrm{ml}$ concentration was chosen for real-time PCR and Western blot analyses.

\section{Real-time PCR and Western blot analyses}

Real-time PCR analysis revealed a modulation of
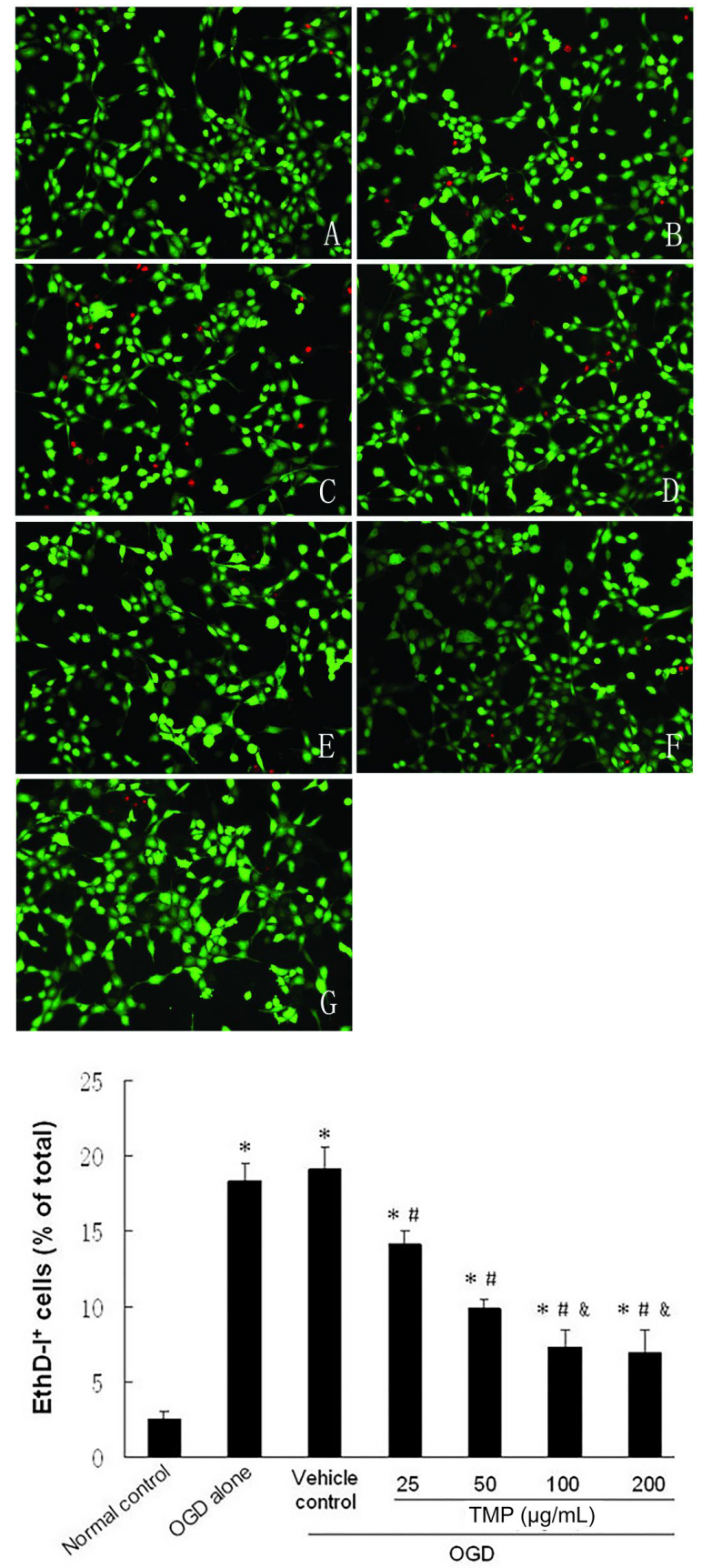

FIGURE 3 - Calcein-AM/EthD-I staining and quantitative evaluation. A: Normal control group; B: OGD alone group; C: Vehicle control group; D: $25 \mu \mathrm{g} / \mathrm{mL}$ TMP group; E: $50 \mu \mathrm{g} / \mathrm{mL}$ TMP group; F: $100 \mu \mathrm{g} / \mathrm{mL}$ TMP group; and G: $20.0 \mu \mathrm{g} / \mathrm{mL}$ TMP group. The magnification is $400 \mathrm{x}$. The viability of Schwann cells was determined with the double-labeling fluorescence technique, whereby living cells, hydrolyzing calcein-AM by intracellular esterases, generate a green fluorescence. Dead cells are labeled with EthD-I, which interacts with DNA resulting in a red fluorescence of cell nuclei. The percentage of dead cells (EthD-I positive) within the total number of Schwann cell profiles in the respective culture was counted and expressed as mean \pm SD. ${ }^{*} P<0.05$ vs. normal control group. ${ }^{\#} P<0.05$ vs. cells exposed to OGD alone. ${ }^{\circledR} P<0.05$ vs. $50 \mu \mathrm{g} / \mathrm{mL}$ TMP group. 


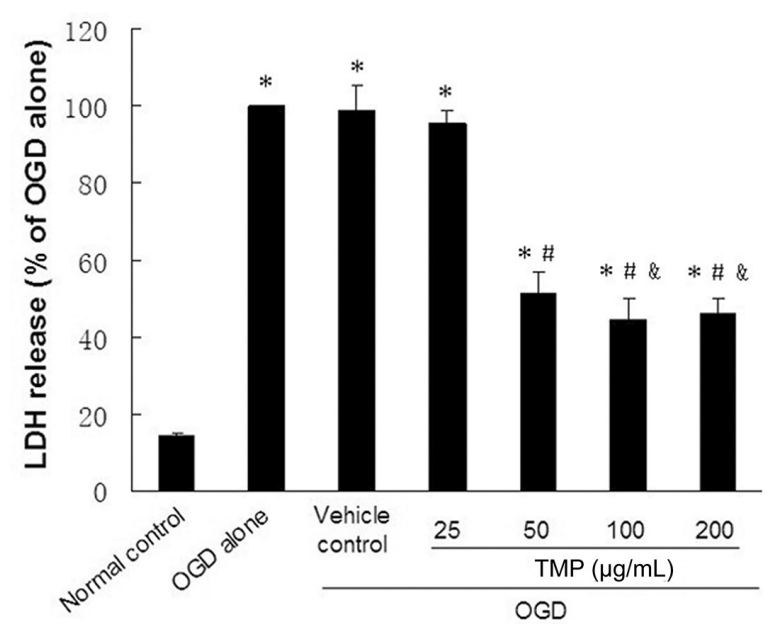

FIGURE 4 - LDH release assay. SC death was evaluated by LDH release into the culture medium. Data are expressed as the mean percentage of the maximal LDH released in the OGD alone group. Values are expressed as mean \pm standard deviation (SD). ${ }^{*} P<0.05$ vs. normal control group. ${ }^{\sharp} P<0.05$ vs. cells exposed to OGD alone. ${ }^{\circledR} P<0.05$ vs. $50 \mu \mathrm{g} / \mathrm{mL}$ TMP group.

apoptosis-relevant genes in SCs exposed to OGD. As shown in Figure 6, the mRNA expression of Bax and caspase-3 genes was significantly increased 1.5-fold compared to the normal control (both $P<0.05$ ), whereas mRNA expression of $\mathrm{Bcl}-2$ was downregulated by approximately $80 \%(P<0.05)$. No significant differences in the expression of $\mathrm{Bax}, \mathrm{Bcl}-2$, and caspase- 3 genes were observed compared to the OGD alone and vehicle control groups (all $P>0.05$ ). Importantly, treatment with TMP inhibited the induction of caspase- 3 and Bax genes expression, whereas expression of Bcl-2 was elevated compared to the OGD alone group (all $P<0.05$ ).

The results from Western blot analyses also proved that the expression of Bax increased, whereas Bcl-2 expression decreased after exposure to OGD. Moreover, the $32 \mathrm{kDa}$ pro-enzyme form of caspase- 3 and its cleavage into the active $17 \mathrm{kDa}$ isoform were both induced by OGD. However, treatment with $100 \mu \mathrm{g} /$ mL TMP significantly inhibited caspase- 3 expression and activation, elevated $\mathrm{Bcl}-2$ levels, and reduced Bax expression relative to the OGD alone group (Figure 7). Taken together, these results clearly demonstrate that TMP can prevent OGD-induced apoptosis by upregulating anti-apoptotic Bcl-2 and downregulating the apoptotic markers Bax and caspase-3.

\section{Study 2}

\section{Electron microscopy}

Histological examination revealed a remarkable
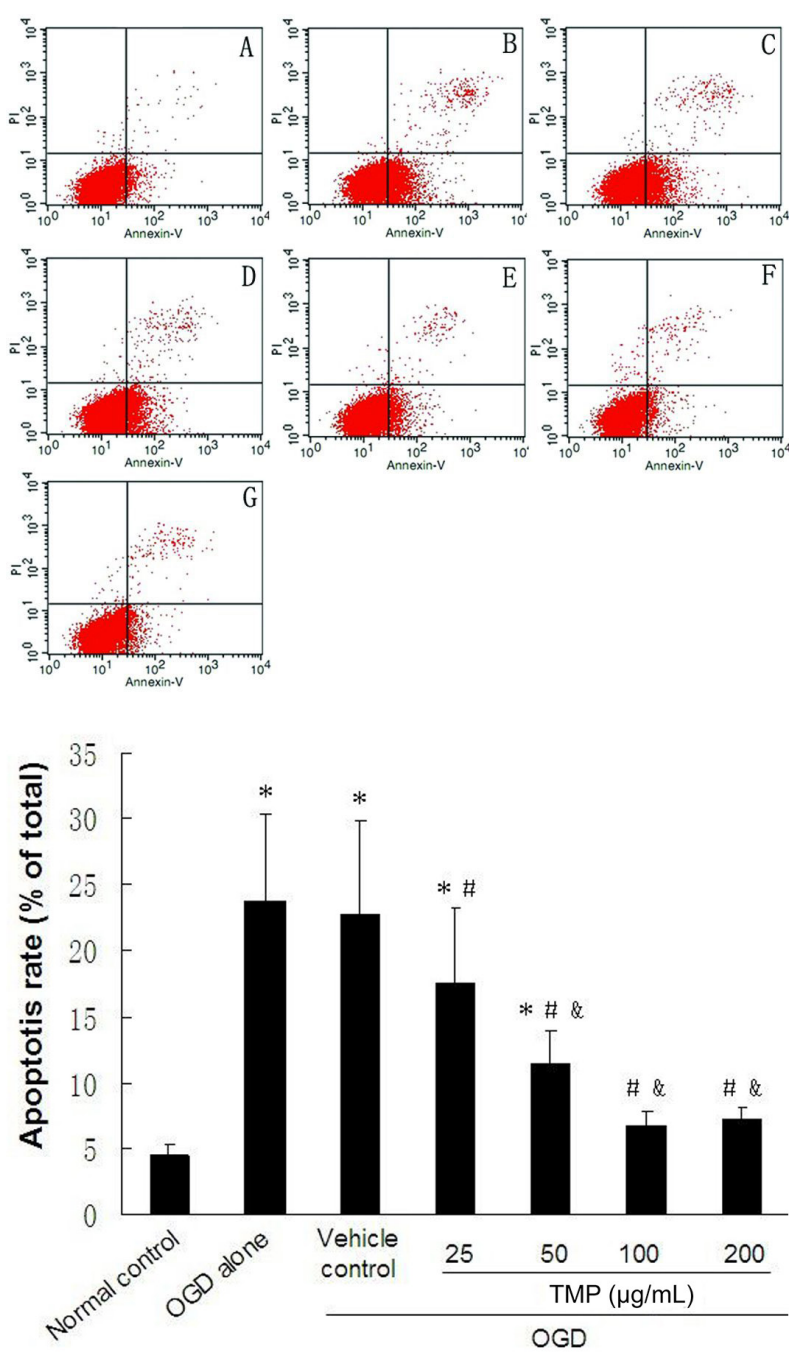

FIGURE 5 - TMP reduces OGD-induced apoptosis of SCs. A: Normal control group; B: OGD alone group; C: Vehicle control group; D: $25 \mu \mathrm{g} / \mathrm{mL}$ TMP group; E: $50 \mu \mathrm{g} / \mathrm{mL}$ TMP group; F: $100 \mu \mathrm{g} / \mathrm{mL}$ TMP group; and G: $200 \mu \mathrm{g} / \mathrm{mL}$ TMP group. The percentage of apoptotic cells detected by annexin V-FITC/ PI staining and flow cytometry. The apoptotic cells included annexin $\mathrm{V}^{+} / \mathrm{PI}^{-}$and annexin $\mathrm{V}^{+} / \mathrm{PI}^{+}$cells. Results are expressed as the mean $\pm \mathrm{SD}$ of five independent experiments. ${ }^{*} P<0.05$ vs. normal control group. ${ }^{\#} P<0.05$ vs. cells exposed to OGD alone. ${ }^{\circledR} P<0.05$ vs. $25 \mu \mathrm{g} / \mathrm{mL}$ TMP group.

difference in the state of nerve segments from each group (Figure 8). In the group treated with $200-400 \mathrm{mg} / \mathrm{mL}$ TMP, there was some evidence of degenerative changes, but the basal lamina as well as the cytoplasmic membrane remained intact and SCs were present. In contrast, the group receiving $100 \mathrm{mg} / \mathrm{ml}$ TMP, as well as the UWS control, had no detectable SCs.

\section{Assessment of nerve graft viability}

In order to verify whether TMP provided a protective effect for nerve segment viability, further analyses using 


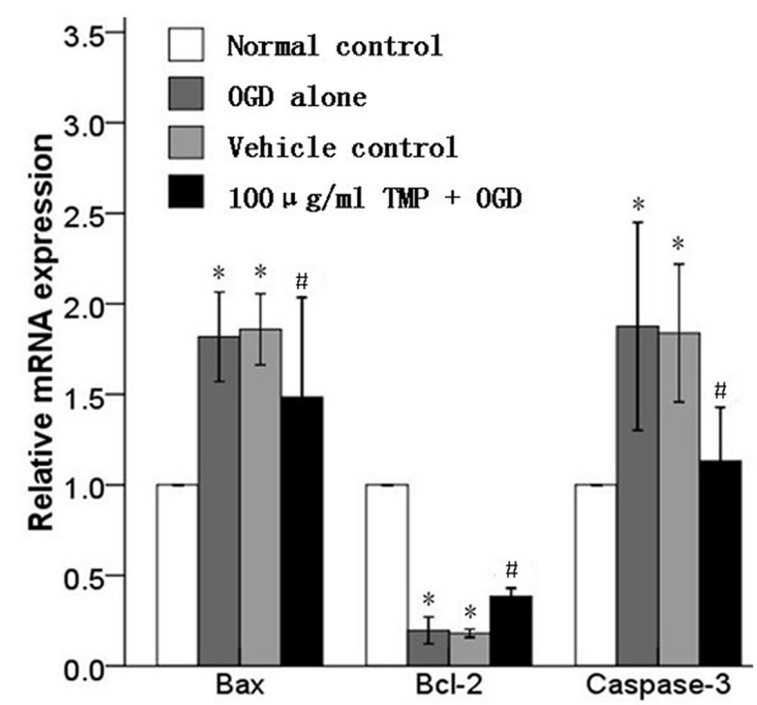

FIGURE 6 - Real-Time PCR analysis of the ratio of Bax, Bcl-2, and caspase- 3 mRNA levels in SCs. The results were expressed as the mean \pm SD. ${ }^{*} P<0.05$ vs. normal control group. ${ }^{\#} P<0.05$ vs. cells exposed to OGD alone.

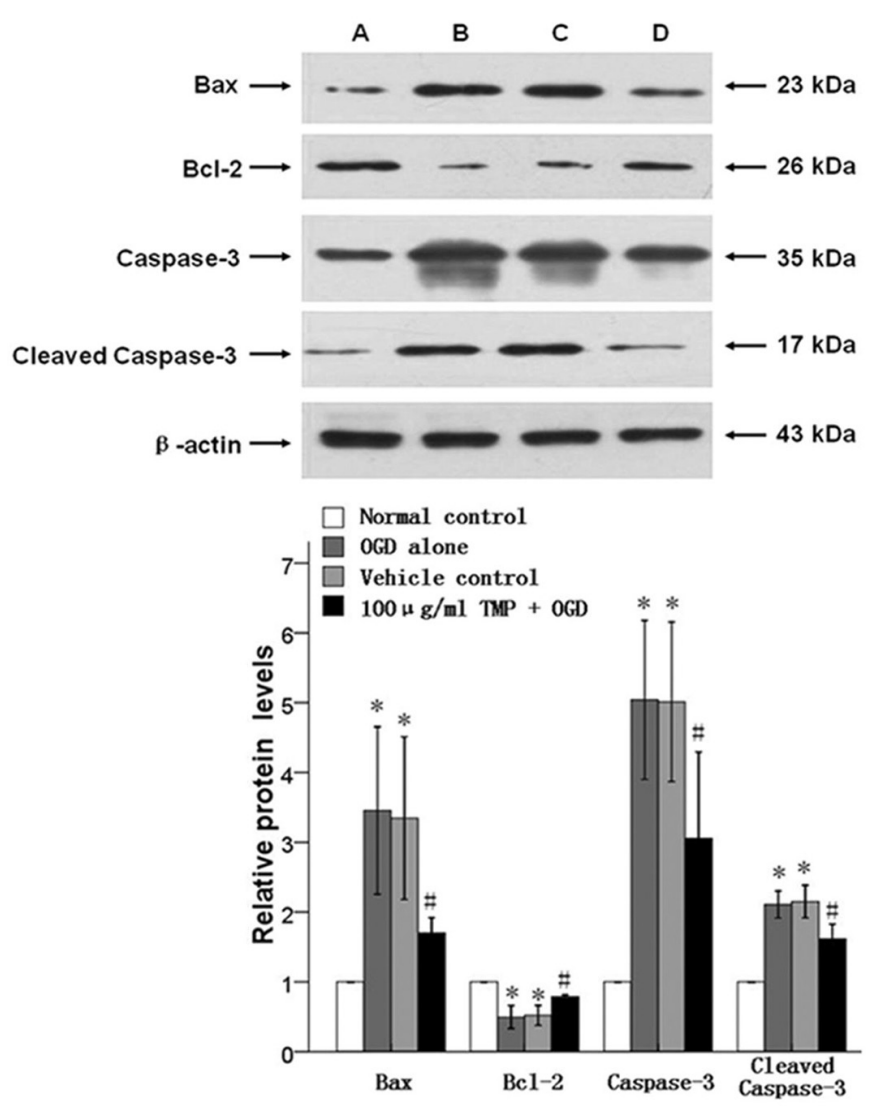

FIGURE 7 - Representative immunoblot of Bax, Bcl-2, caspase-3, and cleaved caspase-3 proteins. A: Normal control group; B: OGD alone group; C: Vehicle control group; and D: $100 \mu \mathrm{g} / \mathrm{ml}$ TMP group. The results were expressed as the mean \pm SD. ${ }^{*} P<0.05$ vs. normal control group. ${ }^{\sharp} P<0.05$ vs. cells exposed to OGD alone.

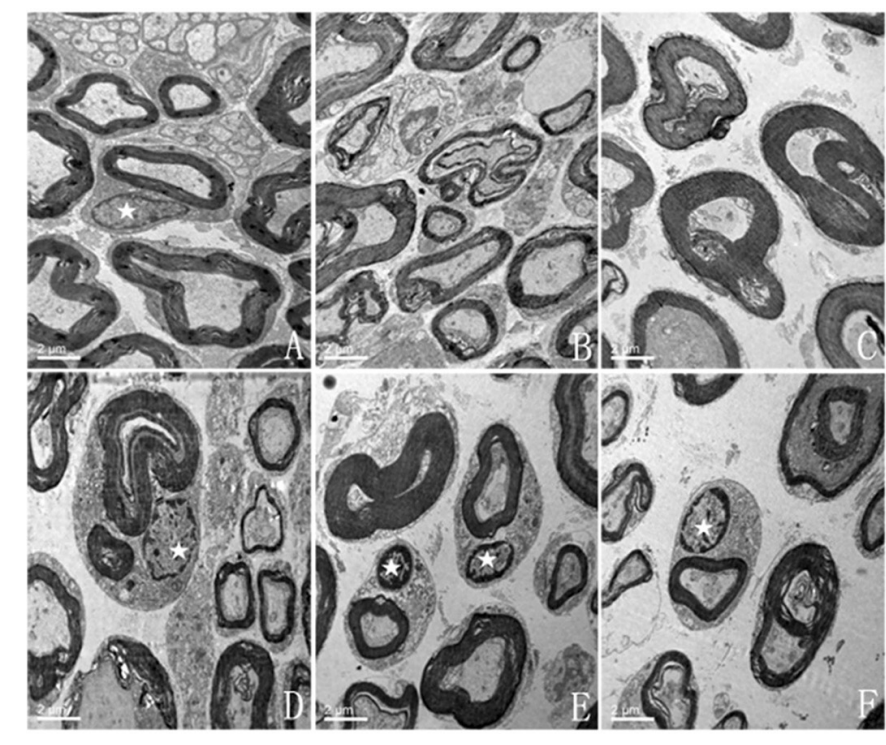

FIGURE 8 - Electron microscopy of Fresh-, TMP-, and UWnerve cross-sections after four weeks of preservation. A: Fresh-nerve group; B: UW-nerve group; C-F: 100-400 mg/mL TMP-nerve group. SCs are preserved in the nerve segments from 200, 300, and $400 \mathrm{mg} / \mathrm{mL}$ TMP-nerve group, while the nerve segments stored for four weeks in $100 \mathrm{mg} / \mathrm{ml} \mathrm{TMP} \mathrm{or}$ UWS alone show myelin breakdown and an absence of SCs. SC nucleus (仿). Scale bars: $2 \mu \mathrm{m}$.

calcein-AM/EthD-I staining were performed. The freshnerve fibers displayed an intense green fluorescence along their entire length with little red fluorescence. There was no clear difference in the confocal microscopic images between the 200, 300, and $400 \mathrm{mg} / \mathrm{mL}$ TMP treatment groups, and intense green fluorescence with dispersed red fluorescence was observed in most nerve fibers. In marked contrast, the $100 \mathrm{mg} / \mathrm{mL}$ TMP-nerve and UW-nerve groups displayed intense red fluorescence with little green staining, indicating that the fibers were dead (Figure 9).

\section{Assessment of nerve graft apoptosis}

Prolonged cold ischemic exposure for four weeks was highly associated with the presence of cell apoptosis in nerve segments preserved with UWS alone. The number of TUNEL-positive cells was dramatically higher in the UW-nerve group compared to the fresh-nerve group $(12.43 \pm 1.62$ vs. $1.71 \pm 0.49 \%$, respectively, $P<0.05)$. In contrast, TUNEL-positive cells were significantly lower in the TMP-treated nerve groups treated with 100, 200, 300 , and $400 \mathrm{mg} / \mathrm{mL}$ compared to the UW-nerve group control $(7.57 \pm 0.98,5.86 \pm 0.90,6.00 \pm 0.82$, and $5.57 \pm 0.79$ vs. $12.43 \pm 1.62 \%$, respectively, all $P<0.05$; Figure 10 ). Therefore, these results indicate that adding TMP into UWS can reduce cell apoptosis in a concentration- 


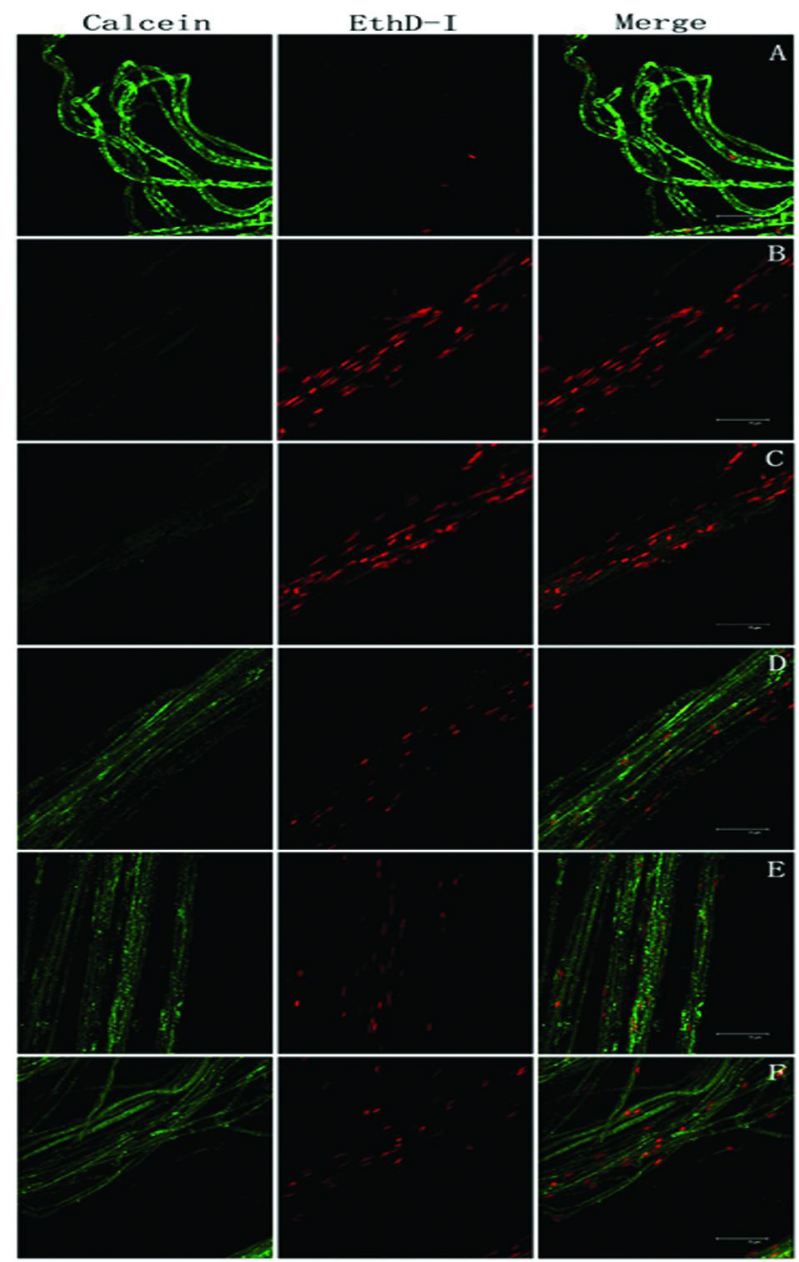

FIGURE 9 - Confocal microscopy of Fresh-, TMP-, and UWnerve fibers stained with calcein-AM/EthD-I. A: Fresh-nerve group; B: UW-nerve group; C-F: 100-400 mg/mLTMP-nerve group. Fresh-nerve fibers present a typical uniform green calcein fluorescence with almost no detectable labeling of the $\mathrm{SC}$ nucleus by red EthD- I fluorescence. Nerve fibers from 200, 300, and $400 \mathrm{mg} / \mathrm{mL}$ TMP-nerve groups display intense green fluorescence with dispersed red fluorescence, while the $100 \mathrm{mg} / \mathrm{mL}$ TMP-nerve and UW-nerve groups have obvious red EthD-I fluorescence, demonstrating that SCs within these fibers are dead. Scale bars: $75 \mu \mathrm{m}$.

dependent manner in a cold ischemic nerve segment model after prolonged ischemia exposure for four weeks.

\section{DISCUSSION}

Ischemic injury can initiate a cascade of events that results in inflammation and cell death by apoptosis and necrosis (Faubel, Edelstein, 2005). Apoptosis is a type of cell death that occurs as a cascade of cellular machinery. It is believed that the ultimate vulnerability of cells to multiple apoptotic stimuli is influenced or determined by the Bcl-2 family (Yang, Korsmeyer, 1996), among
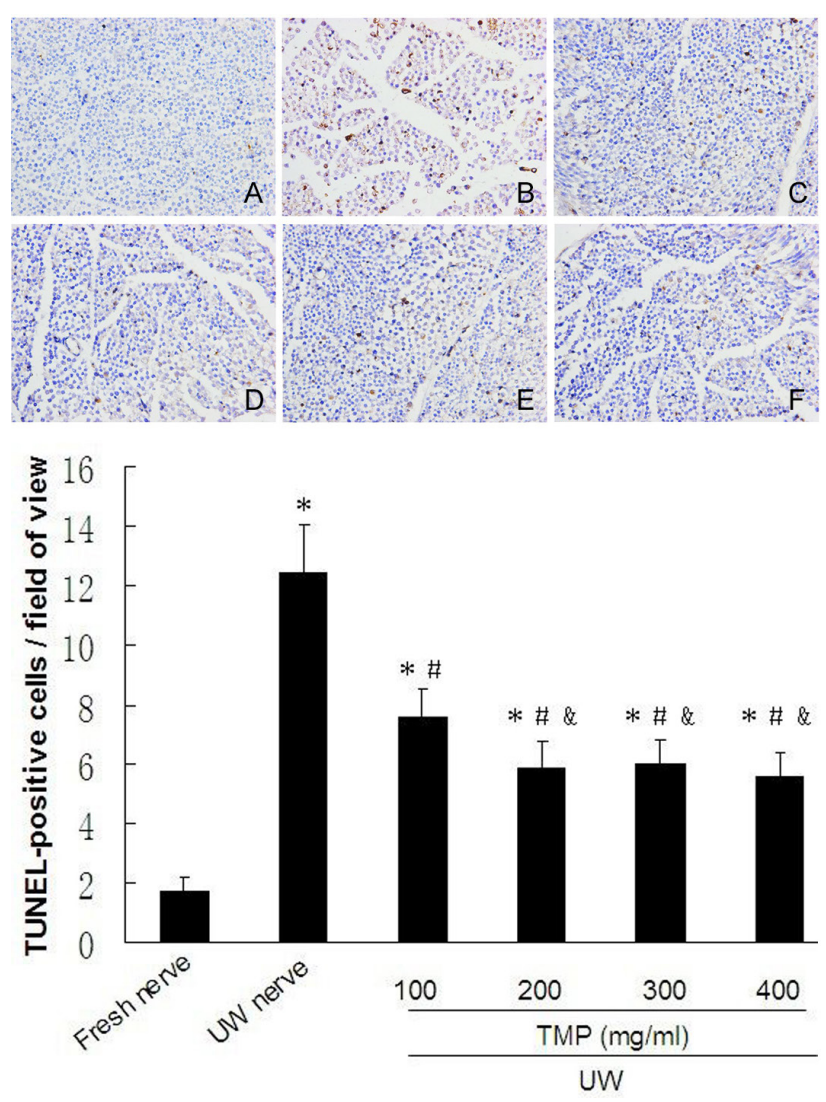

FIGURE 10 - TUNEL-stained nerve sections obtained from each group. A: Fresh-nerve group; B: UW-nerve group; C-F: 100$400 \mathrm{mg} / \mathrm{mL}$ TMP-nerve group. The magnification is $400 \mathrm{x}$. The number of TUNEL-positive cells was counted in five random microscopic fields from each section. Data are expressed as the number of TUNEL-positive cells per field. Values are expressed as mean $\pm \mathrm{SD} .{ }^{*} P<0.05$ vs. Fresh-nerve group. ${ }^{\#} P<0.05$ vs. UW-nerve group. ${ }^{\&} P<0.05 \mathrm{vs.} 100 \mathrm{mg} / \mathrm{mL}$ TMP-nerve group.

which the pro-apoptotic protein Bax plays a dominant role in initiating cell death. The translocation of Bax to the mitochondrial membrane may cause a loss of mitochondrial membrane potential and an increase of mitochondrial permeability, which consequently disrupts the integrity of the mitochondrial membrane, hastens the release of cytochrome $\mathrm{c}$ from the mitochondria, and leads to caspase- 3 activation and ultimately apoptosis (Chinnaiyan et al., 1996; Condorelli et al., 1999). In contrast, the anti-apoptotic protein Bcl-2 of the Bcl2 family, which are potential inhibitors of apoptosis (Henshall et al., 2002; Creson et al., 2009), prevent the release of cytochrome c from mitochondria and caspase activation (Akhtar, Ness, Roth, 2004; Kuhn et al., 2005; Shacka, Roth, 2005) and can inhibit not only caspasedependent apoptosis, but also oxidant-induced apoptosis (Singh, Sharma, Singh, 2007). In addition, caspase-3 is a key initiator and the "executioner caspase" in the 
apoptotic pathway, mediates the cleavage of itself and other downstream caspases, and is centrally important in apoptotic cell death (Liu et al., 1997; Nunez et al., 1998). Therefore, Bax, Bcl-2, and caspase-3, which are all closely involved in the apoptotic pathway, were used as markers to determine the role of TMP in this study.

In Study 1, we demonstrated that TMP could partially alleviate OGD-induced injury of SCs in vitro. Our results from the MTT assay, calcein-AM/EthD-I staining, LDH release assay, and flow cytometry provide evidence that OGD induces a significant decrease in SC survival, whereas TMP preserves cell viability and inhibits OGDmediated apoptosis and LDH release in a dose-dependent manner. Moreover, we found that the maximal protective effect was observed at TMP concentrations of 100 or $200 \mu \mathrm{g} / \mathrm{mL}$. In addition, real-time PCR and Western blot analysis showed that TMP $(100 \mu \mathrm{g} / \mathrm{mL})$ attenuated the OGD-mediated upregulation of the pro-apoptotic protein Bax and downregulation of the anti-apoptotic protein Bcl2 , as well as inhibited the activation of caspase-3. These data suggest that TMP may provide a protective effect against OGD-induced death of SCs in vitro, which may occur through the regulation of Bcl-2 and Bax expression and suppression of caspase- 3 activation.

Previous studies have indicated that TMP has a remarkable neuroprotective effect during ischemic injury. Intraperitoneal administration of TMP was found to significantly protect the brain from ischemic insult, as shown by the reduction in infarction volume, neuronal loss, behavioral disturbance, and brain edema (Liao et al., 2004; Kao et al., 2006). TMP may provide neuroprotection against ischemia brain injury by inducing thioredoxin transcription (Zhu et al., 2009) or by reducing nNOS expression (Xiao et al., 2010). In addition, some studies have reported that TMP has protective effects against cardiovascular diseases and ischemia-reperfusion damage in the kidney (Dai, Bache, 1985; Zhou et al., 2004; Chen et al., 2006; Feng et al., 2011). Moreover, several studies have shown that TMP has potent and effective antiapoptotic activity. TMP was found to attenuate apoptotic injury in rat cerebellar granule cells and the renal tubular cell line NRK-52E after iron-induced or adriamycininduced damage (Zhang et al., 2003; Cheng et al., 2006). The inhibition of $\mathrm{H}_{2} \mathrm{O}_{2}$-induced $\mathrm{PC} 12$ cell apoptosis by TMP may be related to the inhibition of caspase- 3 activation, suppression of cytochrome c release, and increase in the ratio of Bcl-2/Bax (Cheng et al., 2007). The anti-apoptosis activity of Ligusticum chuanxiong, which is the Chinese medicine where TMP originates, may also be mediated through a Protein Kinase A/cAMP Response Element-Binding (PKA/CREB)-dependent pathway in serum deprivation-induced PC12 cell apoptosis (Lin et al., 2007). During rat subarachnoid hemorrhage, TMP may ameliorate cerebral vasospasm by inhibiting the caspase-3-dependent apoptosis pathway (Gao et al., 2008). In spinal cord ischemia-reperfusion injury, alleviation of the damage and inhibition of apoptosis by TMP was linked to Bcl-2 and Bax expression regulation (Fan et al., 2006). Chang et al., demonstrated that TMP may provide neuroprotective effects by inhibiting the activation of Hypoxia-Inducible Factor- 1 alpha (HIF-1 $\alpha$ ), Tumor Necrosis Factor alpha (TNF- $\alpha$ ), and caspase-3, resulting in a reduction in the infarct volume in ischemia-reperfusion brain injury (Chang et al., 2007). Taken together, these studies and our current findings indicate that TMP is an effective anti-apoptotic and ischemic factor that can attenuate ischemia-induced SC death. Based on these in vitro findings, we further investigated if TMP could attenuate ischemia injury and increase graft survival in a cold ischemic rat nerve model after prolonged ischemia exposure, which could be beneficial for peripheral nerve preservation.

Preservation techniques are essential for maintaining graft viability outside of the body prior to transplantation, and optimization of preservation solution components will ultimately help improving transplantation outcomes. A major focus of nerve allograft transplant research has been on preserving nerve tissues without compromising the viability and function of the transplanted nerve tissues. Ultimately, the goal would be to establish a nerve bank where an abundance of nerve graft materials of various sizes and from different HLA-type donors would be available immediately to recipients. To date, there is still no consensus on the optimal nerve graft preservation method that would allow for longer ischemic exposure during preservation without jeopardizing the viability of the graft.

UWS is an intracellular solution characterized by a relatively low sodium and high potassium concentration that is capable of maintaining organ quality over a long period of oxygen deprivation. Moreover, UWS can minimize hypothermic-induced cell swelling, prevent interstitial edema and intracellular acidosis, scavenge oxygen-free radicals, and provide substrates for regenerating high-energy phosphate compounds (Belzer, Southard, 1988). The solution is the gold standard for graft preservation and has been successfully used to preserve explanted liver, heart, and kidney prior to transplantation (Lopez-Andujar et al., 2009; George et al., 2011; Hoeger et al., 2011). Thus, we chose UWS as nerve graft preservation solution in this experiment. In addition, the method for preserving peripheral nerves in UWS at $4{ }^{\circ} \mathrm{C}$ is simple and does not require any specialized equipment. 
Previous studies have tried using UWS for nerve graft preservation in peripheral nerve allotransplantation (Levi et al., 1994; Evans et al., 1995). However, it has been found that while short storage intervals of less than one week in UWS alone resulted in peripheral nerve segments containing functioning SCs, the long-term preservation of peripheral nerve segments for more than three weeks caused a substantial loss of SCs (Levi et al., 1994). SCs outnumber other non-neuronal cells in the peripheral nerve and play an indispensable role in promoting axonal regeneration by providing surface cell adhesion molecules (such as $N$-CAM and Ng-CAM/L1), synthesizing basement membrane components containing extracellular matrix proteins (such as laminin and fibronectin), and producing several neurotrophic factors and receptors (Fu, Gordon, 1997; Siemionow, Brzezicki, 2009). Most pretreatment methods, such as chemical treatment, irradiation, freezing, lyophilization, and freezethawing could effectively reduce nerve graft antigenicity; however, nerve regeneration remains inferior to autografts. One problem has been acellularizing the graft (Song, Yang, Russell, 2009), and although short nerve deficits (less than $3 \mathrm{~cm}$ ) can be bridged by acellular grafts, longer deficits may be more dependent upon the presence of donor-derived viable SCs (Hems, Glasby, 1992; Evans et al., 1995; Strauch et al., 1996; Song, Yang, Russell, 2009), because viable SCs are essential for successful axonal regeneration through longer deficits (Hall, 1986; Feneley, Fawcett, Keynes, 1991; Bunge, 1993). Furthermore, Blais, Grenier, Berthod and Sun et al. found that tissueengineered skin or acellular nerve allografts seeded with SCs could improve nerve regeneration (Blais, Grenier, Berthod, 2009; Sun et al., 2009). Therefore, sustaining donor-derived viable SCs of preserved nerve graft until the graft is repopulated with host SCs is a critical feature in determining the outcome of nerve regeneration for peripheral nerve allografts.

Ischemia, even at low temperatures, has been found to be associated with apoptosis (Turkmen et al., 2011) and may be partly responsible for the decrease in viable SCs during nerve graft preservation. Ischemia time has been shown to correlate significantly with apoptosis rate in human cadaveric renal transplants (Castaneda et al., 2003). Moreover, Jani et al. demonstrated that cold ischemia results in pro-apoptotic caspase- $3,-2,-8$, and -9 activation, as well as increased apoptosis and tubular brush-border injury in a model of non-donation after cardiac death (non-DCD) kidney preservation with UWS (Jani et al., 2004). Recently, it was also found that cold ischemia activated caspase- 3 and caused widespread tubular cell apoptosis in DCD kidneys (Jani et al., 2011). The addition of a caspase inhibitor to the preservation solution was found to effectively reduce apoptosis (Natori et al., 1999; Natori et al., 2003; Jani et al., 2004). It was also found that adding green tea polyphenols, which can protect tissues from ischemia, to UWS, resulted in sustaining never graft viability (Ikeguchi et al., 2003). Thus, these studies together with our finding that TMP can protect SCs from ischemic insult, led us to hypothesize that the addition of TMP to UWS may attenuate ischemia injury and increase graft survival after prolonged cold ischemic exposure.

In Study 2, we demonstrated that prolonged cold ischemic exposure for four weeks was highly associated with the absence of viable SCs and an increase in apoptosis in nerves preserved in UWS alone. However, the addition of TMP to the UWS increased graft survival and reduced cell apoptosis in a concentration-dependent manner, with the maximum protective effect observed at a TMP concentration equal to or greater than $200 \mathrm{mg} / \mathrm{mL}$. Therefore, our results have shown that the addition of TMP ( $\geq 200 \mathrm{mg} / \mathrm{mL}$ ) in UWS can improve the cell survival of nerve grafts even after prolonged cold ischemia exposure for four weeks, which indicated that peripheral nerves may be preserved in a TMP solution. However, the exact mechanism by which TMP maintains graft viability and blocks apoptosis in a cold ischemic nerve model will require further studies. In addition, several key questions require further exploration before TMP can be used for routine peripheral nerve storage. For example, additional studies are need to confirm that nerve grafts preserved in a TMP solution after prolonged cold ischemia exposure can indeed be beneficial in the repair of massive nerve deficits and functional regeneration of in vivo models. In addition, we will need to determine the maximum period of time that nerve grafts can be preserved in TMP without any loss in viability.

Taken together, the findings presented here demonstrate that TMP exerts anti-ischemic properties on OGD-induced primary cultured SC injury and apoptosis by abrogating the activation of caspase- 3 and altering the expression of Bcl-2 and Bax. Moreover, the addition of TMP to UWS can improve the preservation properties of the solution for use in nerve grafts by maintaining graft survival and reducing apoptosis in a concentrationdependant manner. Therefore, TMP may be useful in the preservation of nerve grafts for repairing deficits and improving regeneration.

\section{ACKNOWLEDGMENTS}

This work was supported by grants from the traditional Chinese medicine science and technology 
project of Chongqing Municipal Health Bureau (2009$1-10)$.

\section{REFERENCES}

AKHTAR, R. S.; NESS, J. M.; ROTH, K. A. Bcl-2 family regulation of neuronal development and neurodegeneration. Biochim. Biophys. Acta, v.1644, n.2-3, p.189-203, 2004.

BELZER, F. O.; SOUTHARD, J. H. Principles of solid-organ preservation by cold storage. Transplantation, v.45, n.4, p.673-676, 1988.

BLAIS, M.; GRENIER, M.; BERTHOD, F. Improvement of nerve regeneration in tissue-engineered skin enriched with schwann cells. J. Invest. Dermatol., v.129, n.12, p.28952900, 2009.

BROCKES, J. P.; RAFF, M. C.; NISHIGUCHI, D. J.; WINTER, J. Studies on cultured rat Schwann cells. III. Assays for peripheral myelin proteins. J. Neurocytol., v.9, n.1, p.6777, 1980.

BUNGE, R. P. Expanding roles for the Schwann cell: ensheathment, myelination, trophism and regeneration. Curr. Opin. Neurobiol., v.3, n.5, p.805-809, 1993.

CASTANEDA, M. P.; SWIATECKA-URBAN, A.; MITSNEFES, M. M.; FEUERSTEIN, D.; KASKEL, F. J.; TELLIS, V.; DEVARAJAN, P. Activation of mitochondrial apoptotic pathways in human renal allografts after ischemiareperfusion injury. Transplantation, v.76, n.1, p.50-54, 2003.

CHANG, Y.; HSIAO, G.; CHEN, S. H.; CHEN, Y. C.; LIN, J. H.; LIN, K. H.; CHOU, D. S.; SHEU, J. R. Tetramethylpyrazine suppresses HIF-1alpha, TNF-alpha, and activated caspase-3 expression in middle cerebral artery occlusion-induced brain ischemia in rats. Acta Pharmacol. Sin., v.28, n.3, p.327-333, 2007.

CHEN, S. Y.; HSIAO, G.; HWANG, H. R.; CHENG, P. Y.; LEE, Y. M. Tetramethylpyrazine induces heme oxygenase-1 expression and attenuates myocardial ischemia/reperfusion injury in rats. J. Biomed. Sc., v.13, n.5, p.731-740, 2006.

CHENG, C.Y.; SUE, Y.M.; CHEN, C.H.; HOU, C.C.; CHAN, P.; CHU, Y. L.; CHEN, T. H.; HSU, Y. H. Tetramethylpyrazine attenuates adriamycin-induced apoptotic injury in rat renal tubular cells NRK-52E. Planta Med., v.72, n.10, p.888893, 2006.
CHENG, X. R.; ZHANG, L.; HU, J. J.; SUN, L.; DU, G. H. Neuroprotective effects of tetramethylpyrazine on hydrogen peroxide-induced apoptosis in PC12 cells. Cell Biol. Int., v.31, n.5, p.438-443, 2007.

CHINNAIYAN, A. M.; ORTH, K.; O'ROURKE, K.; DUAN, H.; POIRIER, G. G.; DIXIT, V. M. Molecular ordering of the cell death pathway. Bcl-2 and Bcl-xL function upstream of the CED-3-like apoptotic proteases. J. Biol .Chem., v.271, n.9, p.4573-4576, 1996.

CHIU, D. T.; JANECKA, I.; KRIZEK, T. J.; WOLFF, M.; LOVELACE, R. E. Autogenous vein graft as a conduit for nerve regeneration. Surgery, v.91, n.2, p.226-233, 1982.

CHUN-SHENG, L.; HSIAO-MENG, Y.; YUN-HSIANG, H.; CHUN, P.; CHI-FEN, S. Radix salviae miltiorrhizae and Rhizoma ligustici wallichii in coronary heart disease. Chin. Med. J.(Engl), v.4, n.1, p.43-46, 1978.

CONDORELLI, G.; MORISCO, C.; STASSI, G.; NOTTE, A.; FARINA, F.; SGARAMELLA, G.; DE RIENZO, A.; RONCARATI, R.; TRIMARCO, B.; LEMBO, G. Increased cardiomyocyte apoptosis and changes in proapoptotic and antiapoptotic genes bax and bcl-2 during left ventricular adaptations to chronic pressure overload in the rat. Circulation, v.99, n.23, p.3071-3078, 1999.

CRESON, T. K.; YUAN, P.; MANJI, H. K.; CHEN, G. Evidence for involvement of ERK, PI3K, and RSK in induction of Bcl-2 by valproate. J. Mol. Neurosci., v.37, n.2, p.123-134, 2009.

DAI, X. Z.; BACHE, R. J. Coronary and systemic hemodynamic effects of tetramethylpyrazine in the dog. J. Cardiovasc. Pharmacol., v.7, n.5, p.841-849, 1985.

EVANS, P. J.; MACKINNON, S. E.; BEST, T. J.; WADE, J. A.; AWERBUCK, D. C.; MAKINO, A. P.; HUNTER, D. A.; MIDHA, R. Regeneration across preserved peripheral nerve grafts. Muscle Nerve, v.18, n.10, p.1128-1138, 1995.

FAN, L. H.; WANG, K. Z.; CHENG, B.; WANG, C. S.; DANG, X. Q. Anti-apoptotic and neuroprotective effects of Tetramethylpyrazine following spinal cord ischemia in rabbits. BMC Neurosci., v.7, p.48, 2006.

FAUBEL, S.; EDELSTEIN, C. L. Caspases as drug targets in ischemic organ injury. Curr. Drug Targets Immune Endocr. Metabol. Disord., v.5, n.3, p.269-287, 2005. 
FENELEY, M. R.; FAWCETT, J. W.; KEYNES, R. J. The role of Schwann cells in the regeneration of peripheral nerve axons through muscle basal lamina grafts. Exp. Neurol., v.114, n.3, p.275-285, 1991.

FENG, L.; KE, N.; CHENG, F.; GUO, Y.; LI, S.; LI, Q.; LI, $\mathrm{Y}$. The protective mechanism of ligustrazine against renal ischemia/reperfusion injury. J. Surg. Res., v.166, n.2, p.298$305,2011$.

FU, S. Y.; GORDON, T. The cellular and molecular basis of peripheral nerve regeneration. Mol. Neurobiol., v.14, n.1-2, p.67-116, 1997.

GAO, C.; LIU, X.; LIU, W.; SHI, H.; ZHAO, Z.; CHEN, H.; ZHAO, S. Anti-apoptotic and neuroprotective effects of Tetramethylpyrazine following subarachnoid hemorrhage in rats. Auton. Neurosci., v.141, n.1-2, p.22-30, 2008.

GEORGE, T. J.; ARNAOUTAKIS, G. J.; BAUMGARTNER, W. A.; SHAH, A. S.; CONTE, J. V. Organ storage with University of Wisconsin solution is associated with improved outcomes after orthotopic heart transplantation. J. Heart Lung Transplant., v.30, n.9, p.1033-1043, 2011.

HALL, S. M. Regeneration in cellular and acellular autografts in the peripheral nervous system. Neuropathol. Appl. Neurobiol., v.12, n.1, p.27-46, 1986.

HEMS, T. E.; GLASBY, M. A. Comparison of different methods of repair of long peripheral nerve defects: an experimental study. Br. J. Plast. Surg., v.45, n.7, p.497-502, 1992.

HENSHALL, D. C.; ARAKI, T.; SCHINDLER, C. K.; LAN, J. Q.; TIEKOTER, K. L.; TAKI, W.; SIMON, R. P. Activation of Bcl-2-associated death protein and counter-response of Akt within cell populations during seizure-induced neuronal death. J. Neurosci., v.22, n.19, p.8458-8465, 2002.

HESS, J. R.; BRENNER, M. J.; FOX, I. K.; NICHOLS, C. M.; MYCKATYN, T. M.; HUNTER, D. A.; RICKMAN, S. R.; MACKINNON, S. E. Use of cold-preserved allografts seeded with autologous Schwann cells in the treatment of a long-gap peripheral nerve injury. Plast. Reconstr. Surg., v.119, n.1, p.246-259, 2007.

HO, W. K.; WEN, H. L.; LEE, C. M. Tetramethylpyrazine for treatment of experimentally induced stroke in Mongolian gerbils. Stroke, v.20, n.1, p.96-99, 1989.
HOEGER, S.; LUEG, G.; TSAGOGIORGAS, C.; SCHNEIDER, M.; THEISINGER, S.; THEISINGER, B.; FONTANA, J.; WALDHERR, R.; KRAMER, B. K.; SCHNUELLE, P.; YARD, B. UW is superior compared with HTK after prolonged preservation of renal grafts. J. Surg. Res., v.170, n.1, p.e149-e157, 2011.

IKEGUCHI, R.; KAKINOKI, R.; OKAMOTO, T.; MATSUMOTO, T.; HYON, S. H.; NAKAMURA, T. Successful storage of peripheral nerve before transplantation using green tea polyphenol: an experimental study in rats. Exp. Neurol., v.184, n.2, p.688-696, 2003.

ITOH, S.; SHINOMIYA, K.; SAMEJIMA, H.; OHTA, T.; ISHIZUKI, M.; ICHINOSE, S. Experimental study on nerve regeneration through the basement membrane tubes of the nerve, muscle, and artery. Microsurgery, v.17, n.10, p.525-534, 1996.

JANI, A.; LJUBANOVIC, D.; FAUBEL, S.; KIM, J.; MISCHAK, R.; EDELSTEIN, C. L. Caspase inhibition prevents the increase in caspase-3, $-2,-8$ and -9 activity and apoptosis in the cold ischemic mouse kidney. Am. J. Transplant., v.4, n.8, p.1246-1254, 2004.

JANI, A.; ZIMMERMAN, M.; MARTIN, J.; LU, L.; TURKMEN, K.; RAVICHANDRAN, K.; PACIC, A.; LJUBANOVIC, D.; EDELSTEIN, C. L. Perfusion storage reduces apoptosis in a porcine kidney model of donation after cardiac death. Transplantation, v.91, n.2, p.169-175, 2011.

KAO, T. K.; OU, Y. C.; KUO, J. S.; CHEN, W. Y.; LIAO, S. L.; WU, C. W.; CHEN, C. J.; LING, N. N.; ZHANG, Y. H.; PENG, W. H. Neuroprotection by tetramethylpyrazine against ischemic brain injury in rats. Neurochem. Int., v.48, n.3, p.166-176, 2006.

KEILHOFF, G.; SCHILD, L.; FANSA, H. Minocycline protects Schwann cells from ischemia-like injury and promotes axonal outgrowth in bioartificial nerve grafts lacking Wallerian degeneration. Exp. Neurol., v.212, n.1, p.189200, 2008.

KUHN, H. G.; BIEBL, M.; WILHELM, D.; LI, M.; FRIEDLANDER, R. M.; WINKLER, J. Increased generation of granule cells in adult Bcl-2-overexpressing mice: a role for cell death during continued hippocampal neurogenesis. Eur. J. Neurosci., v.22, n.8, p.1907-1915, 2005. 
LEVI, A. D.; EVANS, P. J.; MACKINNON, S. E.; BUNGE, R. P. Cold storage of peripheral nerves: an in vitro assay of cell viability and function. Glia, v.10, n.2, p.121-131, 1994.

LIAO, S. L.; KAO, T. K.; CHEN, W. Y.; LIN, Y. S.; CHEN, S.Y.; RAUNG, S. L.; WU, C. W.; LU, H. C.; CHEN, C. J. Tetramethylpyrazine reduces ischemic brain injury in rats. Neurosci. Lett., v.372, n.1-2, p.40-45, 2004.

LIN, Y. L.; LEE, Y. C.; HUANG, C. L.; LAI, W. L.; LIN, Y. R.; HUANG, N. K. Ligusticum chuanxiong prevents rat pheochromocytoma cells from serum deprivation-induced apoptosis through a protein kinase A-dependent pathway. J. Ethnopharmacol., v.109, n.3, p.428-434, 2007.

LIU, X.; ZOU, H.; SLAUGHTER, C.; WANG, X. DFF, a heterodimeric protein that functions downstream of caspase-3 to trigger DNA fragmentation during apoptosis. Cell, v.89, n.2, p.175-184, 1997.

LIVAK, K. J.; SCHMITTGEN, T. D. Analysis of relative gene expression data using real-time quantitative PCR and the 2(-Delta Delta C(T)) Method. Methods, v.25, n.4, p.402408, 2001.

LOPEZ-ANDUJAR, R.; DEUSA, S.; MONTALVA, E.; SAN JUAN, F.; MOYA, A.; PAREJA, E.; DEJUAN, M.; BERENGUER, M.; PRIETO, M.; MIR, J. Comparative prospective study of two liver graft preservation solutions: University of Wisconsin and Celsior. Liver Transpl., v.15, n.12, p.1709-1717, 2009.

MACKINNON, S. E. Surgical management of the peripheral nerve gap. Clin. Plast. Surg., v.16, n.3, p.587-603, 1989.

MACKINNON, S. E.; HUDSON, A. R. Clinical application of peripheral nerve transplantation. Plast. Reconstr. Surg., v.90, n.4, p.695-699, 1992.

MATSUMOTO, T.; KAKINOKI, R.; IKEGUCHI, R.; HYON, S. H.; NAKAMURA, T. Optimal conditions for peripheral nerve storage in green tea polyphenol: an experimental study in animals. J. Neurosci. Methods, v.145, n.1-2, p.255266, 2005.

NATORI, S.; HIGUCHI, H.; CONTRERAS, P.; GORES, G. J. The caspase inhibitor IDN-6556 prevents caspase activation and apoptosis in sinusoidal endothelial cells during liver preservation injury. Liver Transpl., v.9, n.3, p.278-284, 2003
NATORI, S.; SELZNER, M.; VALENTINO, K. L.; FRITZ, L. C.; SRINIVASAN, A.; CLAVIEN, P. A.; GORES, G. J. Apoptosis of sinusoidal endothelial cells occurs during liver preservation injury by a caspase-dependent mechanism. Transplantation, v.68, n.1, p.89-96, 1999.

NUNEZ, G.; BENEDICT, M. A.; HU, Y.; INOHARA, N. Caspases: the proteases of the apoptotic pathway. Oncogene, v.17, n.25, p.3237-3245, 1998.

SHACKA, J. J.; ROTH, K. A. Regulation of neuronal cell death and neurodegeneration by members of the Bcl-2 family: therapeutic implications. Curr. Drug Targets CNS Neurol. Disord. v.4, n.1, p.25-39, 2005.

SIEMIONOW, M.; BRZEZICKI, G. Chapter 8: Current techniques and concepts in peripheral nerve repair. Int. Rev. Neurobiol., v.87, p.141-172, 2009.

SINGH, M.; SHARMA, H.; SINGH, N. Hydrogen peroxide induces apoptosis in HeLa cells through mitochondrial pathway. Mitochondrion, v.7, n.6, p.367-373, 2007.

SONG, J. W.; YANG, L. J.; RUSSELL, S. M. Peripheral nerve: what's new in basic science laboratories. Neurosurg. Clin. N. Am., v.20, n.1, p.121-131, 2009.

STRAUCH, B.; FERDER, M.; LOVELLE-ALLEN, S.; MOORE, K.; KIM, D. J.; LLENA, J. Determining the maximal length of a vein conduit used as an interposition graft for nerve regeneration. J. Reconstr. Microsurg., v.12, n.8, p.521-527, 1996.

SUN, X. H.; CHE, Y. Q.; TONG, X. J.; ZHANG, L. X.; FENG, Y.; XU, A. H.; TONG, L.; JIA, H.; ZHANG, X. Improving nerve regeneration of acellular nerve allografts seeded with SCs bridging the sciatic nerve defects of rat. Cell Mol. Neurobiol., v.29, n.3, p.347-353, 2009.

TURKMEN, K.; MARTIN, J.; AKCAY, A.; NGUYEN, Q.; RAVICHANDRAN, K.; FAUBEL, S.; PACIC, A.; LJUBANOVIC, D.; EDELSTEIN, C. L.; JANI, A. Apoptosis and autophagy in cold preservation ischemia. Transplantation, v.91, n.11, p.1192-1197, 2011.

XIAO, X.; LIU, Y.; QI, C.; QIU, F.; CHEN, X.; ZHANG, J.; YANG, P. Neuroprotection and enhanced neurogenesis by tetramethylpyrazine in adult rat brain after focal ischemia. Neurol. Res., v.32, n.5, p.547-555, 2010. 
YANG, E.; KORSMEYER, S. J. Molecular thanatopsis: a discourse on the BCL2 family and cell death. Blood, v.88, n.2, p.386-401, 1996.

ZHANG, Z.; WEI, T.; HOU, J.; LI, G.; YU, S.; XIN, W. Ironinduced oxidative damage and apoptosis in cerebellar granule cells: attenuation by tetramethylpyrazine and ferulic acid. Eur. J. Pharmacol., v.467, n.1-3, p.41-47, 2003.

ZHOU, Y.; HU, C. P.; DENG, P. Y.; DENG, H. W.; LI, Y. J. The protective effects of ligustrazine on ischemia-reperfusion and DPPH free radical-induced myocardial injury in isolated rat hearts. Planta Med., v.70, n.9, p.818-822, 2004.
ZHU, X. L.; XIONG, L. Z.; WANG, Q.; LIU, Z. G.; MA, X.; ZHU, Z. H.; HU, S.; GONG, G.; CHEN, S. Y. Therapeutic time window and mechanism of tetramethylpyrazine on transient focal cerebral ischemia/reperfusion injury in rats. Neurosci. Lett., v.449, n.1, p.24-27, 2009.

Received for publication on $07^{\text {th }}$ September, 2013 Accepted for publication on $24^{\text {th }}$ September 2014 
